\title{
Adding tetrahydrofuran to dilute acid pretreatment provides new insights into substrate changes that greatly enhance biomass deconstruction by Clostridium thermocellum and fungal enzymes
}

Vanessa A. Thomas 1,2,7, Bryon S. Donohoe ${ }^{3,7}$, Mi Li4 $^{4,7}$, Yunqiao Pu 4,7, Arthur J. Ragauskas 4,5,7, Rajeev Kumar ${ }^{2,7}$, Thanh Yen Nguyen ${ }^{2,6}$, Charles M. Cai ${ }^{2,7}$ and Charles E. Wyman ${ }^{1,2,6,7^{*}}$

\begin{abstract}
Background: Consolidated bioprocessing (CBP) by anaerobes, such as Clostridium thermocellum, which combine enzyme production, hydrolysis, and fermentation are promising alternatives to historical economic challenges of using fungal enzymes for biological conversion of lignocellulosic biomass. However, limited research has integrated CBP with real pretreated biomass, and understanding how pretreatment impacts subsequent deconstruction by CBP vs. fungal enzymes can provide valuable insights into CBP and suggest other novel biomass deconstruction strategies. This study focused on determining the effect of pretreatment by dilute sulfuric acid alone (DA) and with tetrahydrofuran (THF) addition via co-solvent-enhanced lignocellulosic fractionation (CELF) on deconstruction of corn stover and Populus with much different recalcitrance by C. thermocellum vs. fungal enzymes and changes in pretreated biomass related to these differences.
\end{abstract}

Results: Coupling CELF fractionation of corn stover and Populus with subsequent CBP by the anaerobe C. thermocellum completely solubilized polysaccharides left in the pretreated solids within only $48 \mathrm{~h}$ without adding enzymes. These results were better than those from the conventional DA followed by either CBP or fungal enzymes or CELF followed by fungal enzyme hydrolysis, especially at viable enzyme loadings. Enzyme adsorption on CELF-pretreated corn stover and CELF-pretreated Populus solids were virtually equal, while DA improved the enzyme accessibility for corn stover more than Populus. Confocal scanning light microscopy (CSLM), transmission electron microscopy (TEM), and NMR characterization of solids from both pretreatments revealed differences in cell wall structure and lignin composition, location, coalescence, and migration-enhanced digestibility of CELF-pretreated solids.

Conclusions: Adding THF to DA pretreatment (CELF) greatly enhanced deconstruction of corn stover and Populus by fungal enzymes and C. thermocellum CBP, and the CELF-CBP tandem was agnostic to feedstock recalcitrance. Composition measurements, material balances, cellulase adsorption, and CSLM and TEM imaging revealed adding THF enhanced the enzyme accessibility, cell wall fractures, and cellular dislocation and cell wall delamination. Overall, enhanced deconstruction of CELF solids by enzymes and particularly by C. thermocellum could be related to lignin removal and alteration, thereby pointing to these factors being key contributors to biomass recalcitrance as a barrier to low-cost biological conversion to sustainable fuels.

\footnotetext{
*Correspondence: cewyman@engr.ucr.edu

${ }^{7}$ BioEnergy Science Center (BESC), Oak Ridge National Laboratory, Oak

Ridge, TN, USA

Full list of author information is available at the end of the article
} 
Keywords: Consolidated bioprocessing, Recalcitrance, Yield, Sugar, Fractionation, Tetrahydrofuran

\section{Background}

Combating global climate change requires deployment of energy systems with low net carbon dioxide release [1-3]. Converting the carbon sequestered in lignocellulosic biomass [4-6] such as woody and herbaceous plants and agricultural residues into fuels reduces carbon emissions compared to the current fossil resources as carbon released can be recycled to grow new plants and limited fossil inputs are needed [7-9]. In addition, the US Department of Energy estimated that 0.6-1.6 billion dry tons of non-food biomass could be available annually at an average cost of approximately $\$ 60 /$ dry ton $[10,11]$, enough to displace up to about $80 \%$ of the US gasoline use. Furthermore, the unit energy cost of biomass at this price is about that of petroleum at \$20/barrel [12-15]. Thus, lignocellulosic biomass stands out as an inexpensive, widely available non-food sustainable resource from which enough liquid fuels could be derived to impact energy demands and reduce atmospheric carbon dioxide accumulation.

Saccharification of lignocellulosic polysaccharide to sugars for fermentation to ethanol and other products remains more expensive than petroleum based liquid fuels due to plant cell wall recalcitrance to chemical, physical, or biological deconstruction [15-17]. Trichoderma reesei fungal enzymes have been historically applied to break down plant cell walls $[18,19]$, but enzymes are estimated to cost $\sim \$ 0.70-\$ 1.50 /$ gal ethanol at loadings that achieve viable yields from even relatively low-recalcitrant corn stover [20, 21]. Although tradeoffs among pretreatment types and conditions and fungal enzyme cocktails and loadings have been researched for various lignocellulosic feedstocks [22-26], enzyme costs remain too high $[20,27,28]$, and it is desirable to explore new routes to achieving high yields from biological deconstruction.

Consolidated bioprocessing (CBP) by anaerobes such as Clostridium thermocellum that produce cellulolytic enzymes and ferment sugars released is a promising alternative to separate fungal enzyme production and subsequent hydrolysis [29-34]. Research on CBP by $C$. thermocellum and other organisms is progressing at various laboratories to achieve industrially relevant ethanol selectivities (>90\%), titers (>50 g/L), and yields (>90\%). For example, the Lynd's group at Dartmouth College, $\mathrm{NH}$ recently showed that more than $20 \mathrm{~g} / \mathrm{L}$ of ethanol can be produced from Avicel cellulose with a yield of about $75 \%$ of the theoretical maximum [35]. However, little attention has yet to be given to integration of $\mathrm{CBP}$ organisms with pretreated real biomass, and it is important to understand whether CBP can realize deconstruction yields competitive with those from conventional pretreatment followed by fungal enzyme hydrolysis and the robustness of CBP to changes in feedstock type [36, 37]. In this study, the following two distinctive pretreatments were applied to two substrates with much different recalcitrance, corn stover and Populus, to meet these objectives: (1) conventional dilute acid pretreatment in light of its previously shown versatility with multiple feedstocks $[26,38,39]$ and its favored position [40, 41]; and (2) a new pretreatment that applies a miscible solution of tetrahydrofuran (THF) with dilute acid in a technology labeled co-solvent enhanced lignocellulosic fractionation [42]. References to the two are labeled as DA and CELF, respectively, throughout this paper. CELF was chosen to understand how separating a large fraction of major biomass components from one another influences deconstruction of these diverse feedstocks by enzymes and $C$. thermocellum compared to use of dilute acid alone [43]. Although other solvents such as ethanol or methanol (i.e., organosolv that has been studied for over 30 years), newly described gamma valerolactone (GVL), and recent reemergence of ionic liquids could have been employed as pretreatments in this study with likely similar results [25, 44], CELF was selected to take advantage of our extensive experience with optimizing this technology. It is recognized that CELF, as for other solvent pretreatments, has yet to be proven to substantially lower overall process costs or increase revenues through lignin valorization, but THF has important advantages relative to other solvent pretreatments, including low boiling point $\left(66{ }^{\circ} \mathrm{C}\right)$, a high azeotrope concentration in water $(95 \% \mathrm{w} / \mathrm{w})$, which facilitate $97 \%$ commercial recovery [45], multiple routes to recovery and recycle, and production from xylose at high yields that can facilitate sustainable replenishment [46]. In addition to determining performance of $C$. thermocellum CBP applied to solids produced by pretreated feedstocks for the first time, enzyme adsorption, changes in biomass and lignin composition, and stereomicroscopy, confocal scanning light microscopy (CSLM), and transmission electron microscopy (TEM) imaging were applied to identify distinctive features of the solids produced by CELF and DA pretreatments of each feedstock that could explain deconstruction differences between CBP and fungal enzyme systems and thereby provide valuable insights that can suggest novel routes to lower the cost of biomass conversion to fuels. 


\section{Results and discussion}

\section{CELF and DA deconstruction of corn stover and poplar wood}

The BioEnergy Science Center (BESC) through Oak Ridge National Laboratory (ORNL, Oak Ridge, TN) and the National Renewable Energy Laboratory (NREL, Golden, CO) provided BESC standard Populus (Populus trichocarpa) and corn stover, Zea mays, respectively, with compositions of each being reported in the Additional file 1. As illustrated in Fig. 1, CELF and conventional DA [40, 47-49] pretreatments were applied to each feedstock followed by breakdown of the pretreated solids by fungal enzymes over a range of loadings or C. thermocellum CBP without enzyme supplementation. Based on our experience in optimizing DA and CELF, both pretreatments were with $0.5 \mathrm{wt} \%$ sulfuric acid in water but with addition of equal THF volumes to the acid/water solution for CELF [42]. Lower solids loadings than desired commercially were used to avoid mass-transfer limitations that otherwise can confound the main findings. Combinations of pretreatment temperatures and times were defined to maximize total glucose plus xylose yields from each substrate from the combined pretreatment (Stage 1 in Fig. 1) and subsequent hydrolysis (Stage 2 in Fig. 1) of washed pretreated solids by Accellerase ${ }^{\circledR} 1500$ enzyme [27, 42]. For the latter, $100 \mathrm{mg}$-protein/g-glucan was needed to maximize total sugar yields from Populus, but $15 \mathrm{mg}$-protein/g-glucan was adequate for corn stover due to its lower recalcitrance [26]. For DA, $160{ }^{\circ} \mathrm{C}$ for 25 min gave the highest combined total sugar yields from Populus, while the one for $20 \mathrm{~min}$ at $160{ }^{\circ} \mathrm{C}$ realized this goal for less-recalcitrant corn stover. For CELF of Populus, $160{ }^{\circ} \mathrm{C}$ achieved the highest Stage 1 plus Stage 2 total sugar yields but in just $15 \mathrm{~min}$. However, for CELF of corn stover, $150{ }^{\circ} \mathrm{C}$ for $25 \mathrm{~min}$ achieved the maximum sugar yield [42]. At these conditions, DA removed less than $2 \%$ of Klason-lignin in both raw materials, while CELF delignified 82.6 and $75.6 \%$ of Populus and corn stover, respectively. DA pretreatment hydrolyzed 92.4 and $90.2 \%$ of xylan from Populus and corn stover, respectively, whereas CELF removed 89.5 and $95.4 \%$, respectively. Over $90 \%$

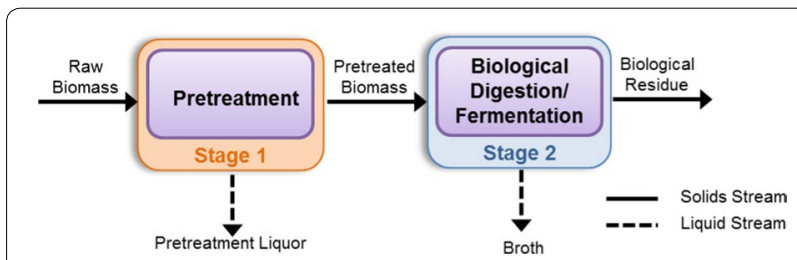

Fig. 1 Material flow for dilute acid and CELF pretreatments of corn stover and poplar wood followed by biological deconstruction mediated of the pretreated and washed solids by Clostridium thermocellum CBP at $60^{\circ} \mathrm{C}$ or fungal enzymes at $50{ }^{\circ} \mathrm{C}$ of glucan remained in solids after both pretreatments. Overall, removals of xylan, glucan, and lignin by both DA and CELF were consistent between the two feedstocks, but CELF solids had a considerably higher percent glucan due to greater lignin solubilization. Additional file 1: Table S1 summarizes compositions of solids from each pretreatment at conditions that maximized sugar yields.

\section{Biological deconstruction of CELF- and DA-pretreated solids}

Solids from DA and CELF at the conditions above were washed thoroughly to remove THF and other solubles and hydrolyzed at initial glucan loadings of $5 \mathrm{~g} / \mathrm{L}$ of glucan. Fungal enzymatic hydrolysis experiments were run in triplicates at $50{ }^{\circ} \mathrm{C}$ with enzyme loadings of 2,5 , and $15 \mathrm{mg}$ of Accellerase ${ }^{\circledR} 1500$ protein/g glucan in biomass before pretreatment. Because these enzyme loadings are projected to cost about $\$ 0.10,0.25$, and $0.75 /$ gallon ethanol, respectively, only the lowest is likely to be economically viable $[20,50]$. Solids from each pretreatment at optimal conditions were deconstructed in duplicate experiments by $C$. thermocellum at $60{ }^{\circ} \mathrm{C}$ for the solids loading of $5 \mathrm{~g}$ glucan/L for up to $168 \mathrm{~h}$. Although higher solids levels are desired commercially, low solids loadings were used to focus on deconstruction and avoid C. thermocellum inhibition by pretreatment products, culture conditions, and/or hydrolysis products, the latter being also true for fungal systems $[24,51,52]$.

Figure 2 summarizes how corn stover vs. Populus recalcitrance and DA vs. CELF impacted the time course and final yields for deconstruction at three loadings of fungal enzymes vs. $C$. thermocellum. As expected, Fig. 2 demonstrates that corn stover was more amenable to deconstruction than Populus for fungal hydrolysis of DA or CELF solids. However, comparing Fig. $2 \mathrm{a}-\mathrm{d}$ shows that CELF solids were far more easily deconstructed than DA solids regardless of feedstock or biological system. Furthermore, Fig. 2 shows that only the highest fungal enzyme loadings could release as much glucan and xylan from solids produced by DA of corn stover as $C$. thermocellum, while $C$. thermocellum clearly surpassed sugar release by application of even the highest fungal enzyme loadings to solids produced by DA or CELF pretreatments of Populus. CELF-pretreated corn stover solids were highly digestible even at $2 \mathrm{mg}$ protein with $>80 \%$ glucan plus xylan yield after 7 days; however, consistent with our previous findings, achieving an approximately 95\% yield required longer incubation times of 14 days [42]. Most strikingly, CELF followed by C. thermocellum virtually completely deconstructed solids from CELF-pretreated corn stover and Populus in just 2 days, eliminating differences in polysaccharide recalcitrance between the two feedstocks. Thus, in addition to high 

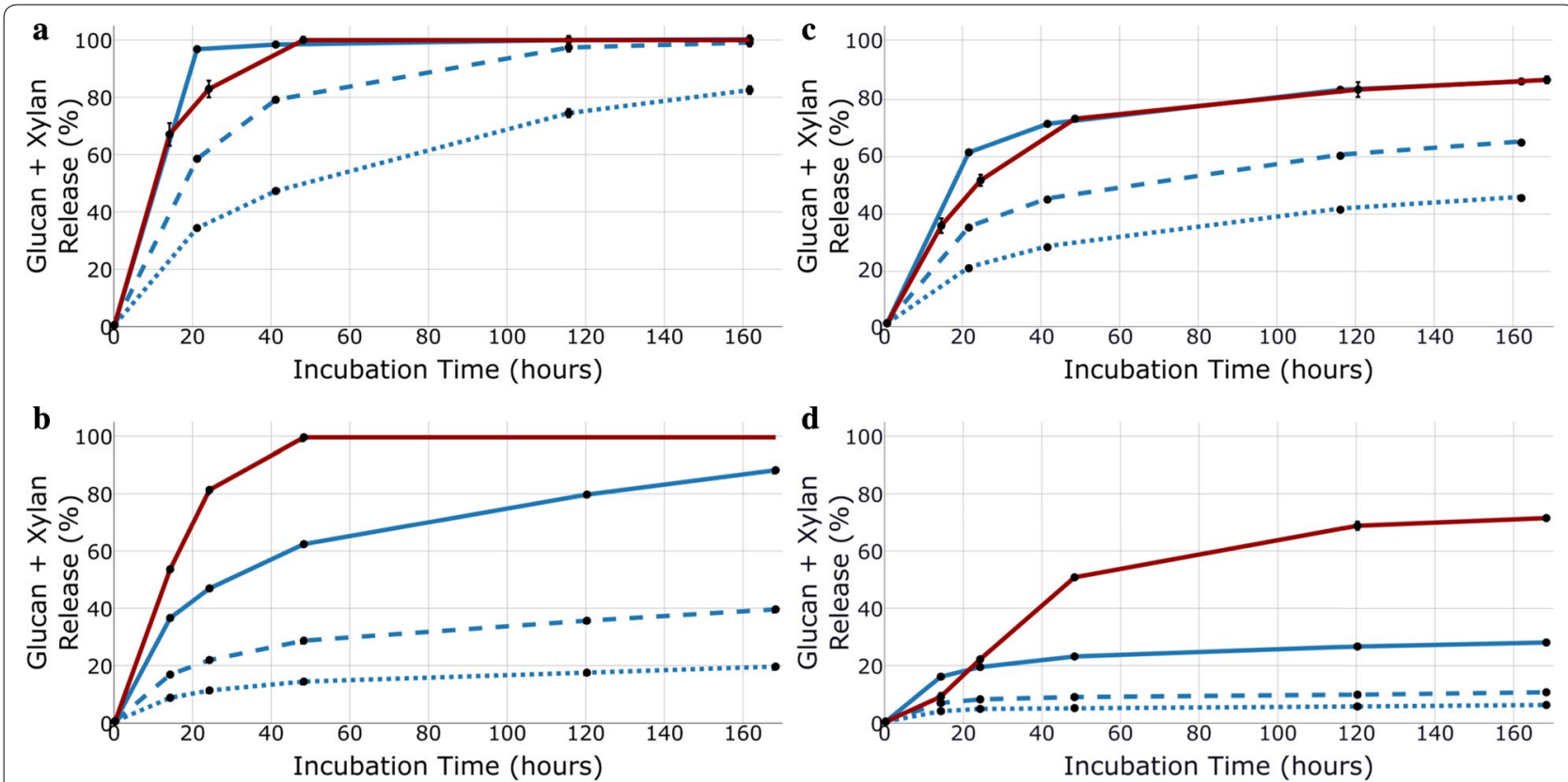

\section{$\rightarrow$ C. thermocellum $\quad-\bullet-5 \mathrm{mg}$ protein/g glucan
$\rightarrow 15 \mathrm{mg}$ protein/g glucan $\cdots \bullet-2 \mathrm{mg}$ protein/g glucan}

Fig. 2 Glucan plus xylan releases from hydrolysis of solids produced by CELF pretreatment of (a) corn stover and (b) Populus and DA pretreatment of (c) corn stover and (d) Populus by fungal enzymes at $50^{\circ} \mathrm{C}$ at loadings of 2, 5, and $15 \mathrm{mg}$ of total enzyme protein/g glucan in biomass before deconstruction and by C. thermocellum ( $2 \% \mathrm{v} / \mathrm{v}$ inoculum) at $60^{\circ} \mathrm{C}$. Because C. thermocellum fermentation of CELF-pretreated solids was complete in $48 \mathrm{~h}$, its 120- and 168-h time points are extensions of 48-h sugar release. All anaerobic digestion and enzymatic hydrolysis experiments were run in duplicate with mean values shown. Error bars in the graph are one standard deviation. The sugar release for enzymatic hydrolysis refers to sugars recovered in the solution as determined by direct measurement. Sugar release for CBP refers to the amount of sugars solubilized as determined by analysis of the carbohydrates in the residual solids

yields in shorter times, the CELF-CBP tandem was virtually unaffected by differences in feedstock recalcitrance while DA followed by fungal hydrolysis was.

\section{Substrate accessibility and enzyme effectiveness}

As Additional file 1: Figures S1 and S2 show, CELF followed by C. thermocellum CBP achieved near-theoretical glucan and xylan releases from both corn stover and Populus, thus overcoming recalcitrance. Because pretreated solids composition and material balances showed similar hemicellulose removal but major differences in lignin solubilization, the much lower lignin content of CELFpretreated solids (Additional file 1: Table S1) appeared to promote polysaccharide deconstruction.

As a next step to understand enhanced deconstruction by CELF, cellulase adsorption on CELF- and DA-pretreated corn stover (CELF-CS and DA-CS, respectively) and Populus (CELF-POP and DA-POP) was measured for cellulase concentrations of $0.01-2.0 \mathrm{mg}$ protein $/ \mathrm{mL}$ [53]. Figure 3 shows that CELF-CS solids adsorbed more cellulase than DA-CS solids at higher enzyme concentrations, while enzyme adsorption was similar at low enzyme

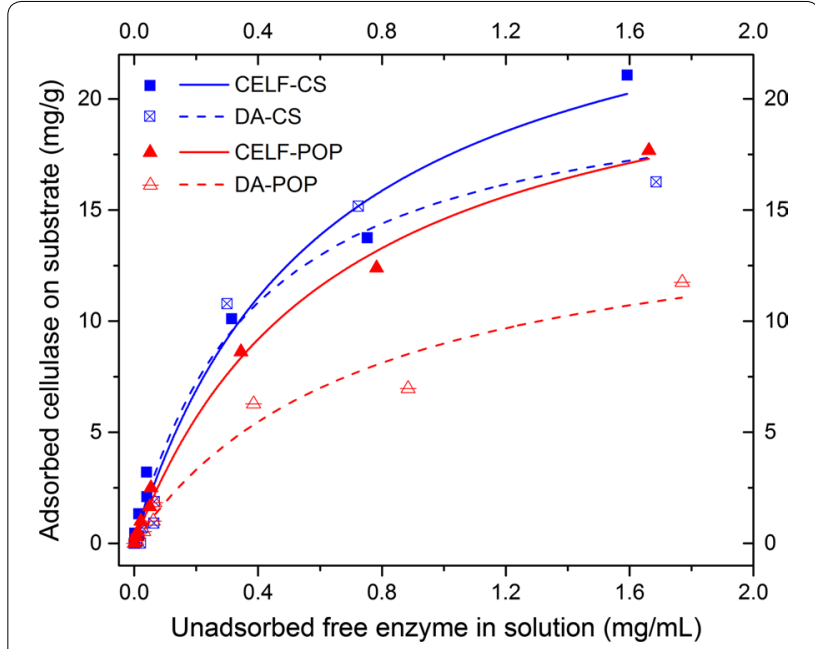

Fig. 3 The amount of cellulase adsorbed at $4{ }^{\circ} \mathrm{C}$ on solids from CELF and DA pretreatments of corn stover (CELF-CS and DA-CS, respectively) and Populus (CELF-POP and DA-POP, respectively) as a function of cellulase remaining in solution for protein concentrations of $0.01-2 \mathrm{mg} / \mathrm{mL}$. Curve fitting was according to the Langmuir adsorption model. $R^{2}$ values: CELF-CS, 0.98; DA-CS, 0.96; CELF-POP, 1.0; and DA-POP, 0.97 
concentrations. For Populus, differences in enzyme adsorption were far more pronounced and grew more so with the increasing enzyme concentration. Adsorption on solids from CELF pretreatment of both corn stover and Populus are almost identical but much different on solids from DA pretreatment of both. Enzyme adsorption similarities on CELF solids align with deconstruction patterns for $C$. thermocellum deconstruction of the two and helps explain why CELF-CBP is agnostic to feedstock recalcitrance. On the other hand, disparities between enzyme adsorption on CELF- and DA-corn stover solids are less than those for Populus. Reactions of enzyme with substrates are complex and affected by physiochemical properties such as surface features, cellulose ultrastructure, and lignin and hemicellulose [54, 55]. The larger difference in enzyme adsorption kinetics for Populus suggests CELF increased enzyme adsorption more for Populus than for corn stover compared with DA.

Langmuir nonlinear regression model parameters for the adsorption curve fits in Fig. 3 revealed that the maximum amount of enzyme adsorbed, $\Gamma_{\max }$, was similar for CELF-CS and CELF-POP at 28.0 and $24.0 \mathrm{mg} / \mathrm{g}$ biomasses, respectively, but dropped to $21.4 \mathrm{mg} / \mathrm{g}$ for DA-CS and even more to only $15.7 \mathrm{mg} / \mathrm{g}$ for DA-POP. The greater enzyme adsorption on CELF corn stover and Populus solids could be due to their significantly lower lignin content resulting in greater cellulose accessibility that outweighed enzyme adsorption on the much greater lignin content of DA solids. The slight drop in enzyme adsorption capacity of DA-CS solids and reduced yields and rates of deconstruction by enzymes and CBP in Fig. 2 supports the possibility that a meaningful portion of enzymes was tied up nonproductively on lignin. The Langmuir-binding affinity constant $K$ that is indicative of enzyme affinity for substrate was very similar for CELFCS, CELF-POP, and DA-POP at 1.6, 1.5 , and $1.3 \mathrm{~mL} / \mathrm{mg}$, respectively, but rose to 2.6 for DA-CS. However, the fact that rates and yields from DA-CS were lower than from CELF-CS and CELF-POP in Fig. 2 suggests that binding affinity does not significantly impact deconstruction, consistent with higher lignin content in DA solids nonproductively tying up a significant fraction of enzyme. Overall, the Langmuir parameters suggest that enzyme accessibility to substrate, $\Gamma_{\max }$, outweighs the impact of binding affinity, $K$, on biomass deconstruction. One hypothesis to explain this result is that the significant enhancement of lignin removal by CELF compared with DA, while achieving similar hemicellulose removal to DA [55] increased enzyme accessibility to solids and their effectiveness so much that enzyme binding did not limit faster, more complete deconstruction of the CELF solids by enzymes or $C$. thermocellum.

\section{Specific lignin relocation and removal}

Confocal scanning light microscopy (CSLM) and transmission electron microscopy (TEM) provided insights into differences in disruption of structural features of solids by CELF vs. DA that could account for enhanced deconstruction by enzymes and C. thermocellum and explain why CELF-CBP was agnostic to feedstock recalcitrance. Compared to CSLM images in Figures S3 and S4 for raw corn stover and Populus, CSLM micrographs in Fig. 4 show minor dislocation and fracturing (white arrows) for DA-CS and DA-POP. In addition, DA-POP scattered spherical droplets from lignin coalescence (white arrowheads) throughout these images. By comparison, the CSLM micrographs of CELF-CS and CELFPOP in Fig. 4 show much more cell wall delamination, dislocation, and fracturing (white arrows) no droplets as a result of extensive lignin removal. This difference in lignin removal could explain why CELF solids have greater Langmuir enzyme adsorption capacities than DA solids. Although these results do not explain why the binding affinity was so much greater for DA than CELF solids from corn stover or Populus or DA-POP, the much greater lignin content of DA compared with CELF solids could bind far more enzyme [56].

TEM micrographs of corn stover fiber and Populus cell walls and corners in Figs. 5 and 6 reveal lignin coalescence in the middle lamella and cell wall corners due to migration from the secondary cell wall during DA pretreatment. Lignin coalescence was clearly evident through preferential $\mathrm{KMnO}_{4}$ staining of lignin in embedded, sectioned samples (white arrowheads). This interpretation of lignin droplet formation is consistent with previous scanning electron microscopy (SEM) and TEM coupled with electron dispersive spectroscopy (EDS) and NMR analysis that identified electron dense globules as lignin that migrated and coalesced during DA pretreatment of corn stover rind [57]. Additional lignin coalescence was visible in the cell lumen likely due to extrusion from the secondary cell wall through delamination (white arrowheads).

Figures 5 and 6 also show TEM micrographs of cell walls and corners in CELF-CS and CELF-POP solids. The low stain density is consistent with CELF removing significant amounts of lignin from both feedstocks, and TEM micrographs reveal a loose morphology for both. The TEM images also show that CELF increased delamination (white arrows) of corn stover and produced clearly visible cellulose microfibrils and surface erosion of Рориlus. The soft edges of primary and secondary cell walls indicate delamination and loose, splayed fibrils made visible by CELF pretreatment of both feedstocks. Thus, in addition to reinforcing CSLM and enzyme adsorption 

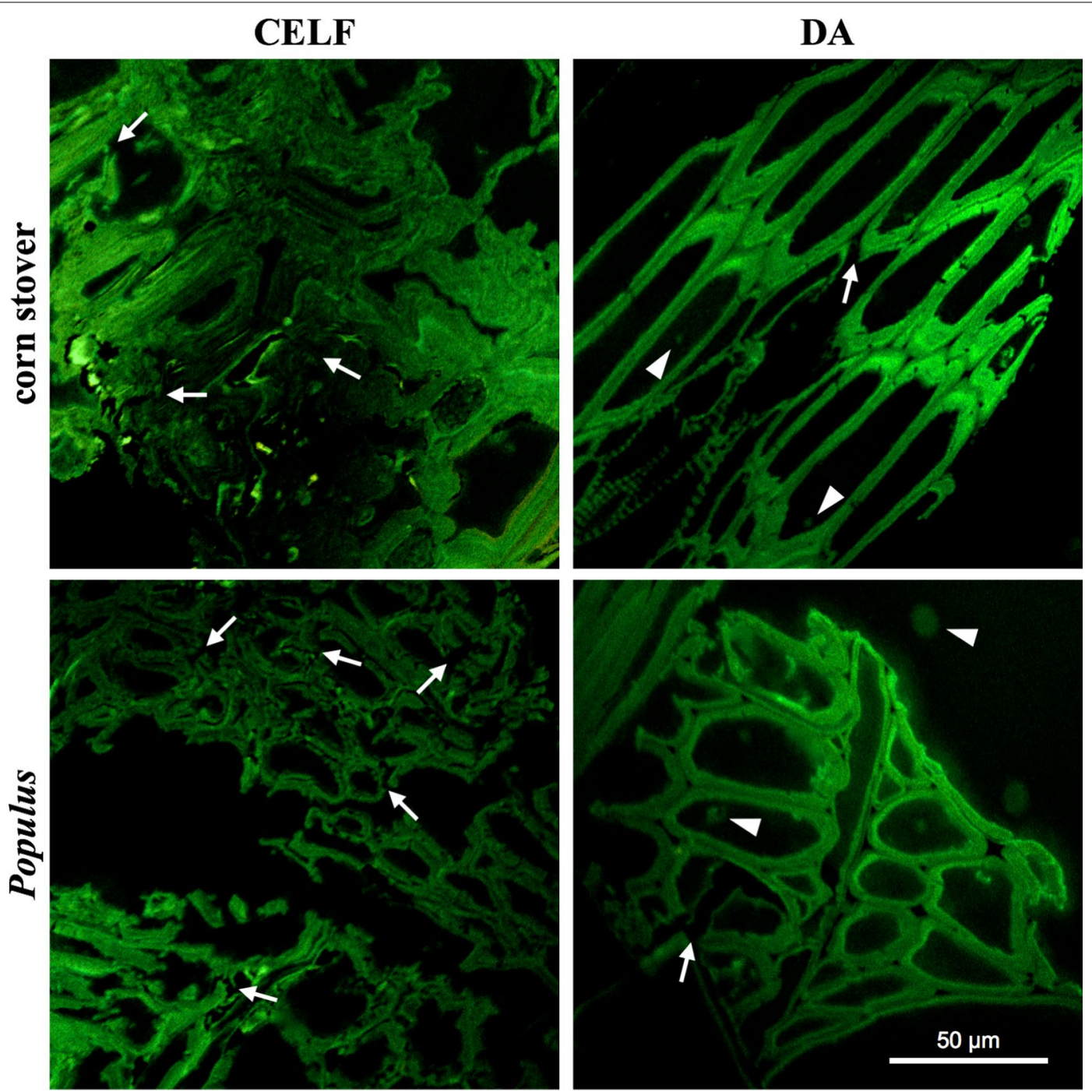

Fig. 4 CSLM micrographs of solids produced by CELF (left) and DA (right) pretreatment of corn stover (top) and Populus (bottom). Micrographs are of oblique tissue cross sections. Arrows indicate regions of dislocation and fracturing and arrowheads point out coalesced lignin

insights that CELF lignin removal produced, a cleaner surface with greater cellulose accessibility, devoid of lignin deposits that can interfere with enzymes, and had less lignin to nonproductively adsorb enzymes [58], TEM images show that CELF opens up internal cell wall architecture so fungal enzymes and C. thermocellum can more readily attack cellulose and achieve greater rates and cellulose deconstruction than from DA. The stereoscope imaging in Figure S5 shows CELF produced smaller fibers from corn stover and more particle swelling in Populus compared to DA.

Because lignin composition has been thought to strongly influence biomass recalcitrance [59], HSQC NMR was applied to measure the relative abundance of major syringyl (S) and guaiacyl (G) monolignol subunits and their ratios in both Populus and corn stover. In addition, $p$-coumarate ( $p$ CA), ferulate (FA), and tricin in corn stover; and $p$-hydroxybenzoate (PB) in Populus were measured for solids before and after application of the two pretreatments. Key results are summarized here, with more complete data in the Additional file 1. Both CELF and DA pretreatments increased the $S$ lignin fraction and reduced $\mathrm{G}$ lignin for both feedstocks. CELF almost completely removed corn stover $\mathrm{G}$ units (Additional file 1: Figure S6 and Table S2), while DA only increased the corn stover S/G ratio slightly (from 0.83 to 0.93 ). For Populus in Additional file 1: Figure S7 and Table S2, both CELF and DA increased the $S / G$ ratio slightly from 1.82 in untreated Populus to 2.04 and 2.09, respectively. Two-dimensional (2D) NMR lignin spectra revealed that tricin and FA were only detectable at noise level in DA-CS and completely removed for CELF-CS (Additional file 1: Figure S6 and 


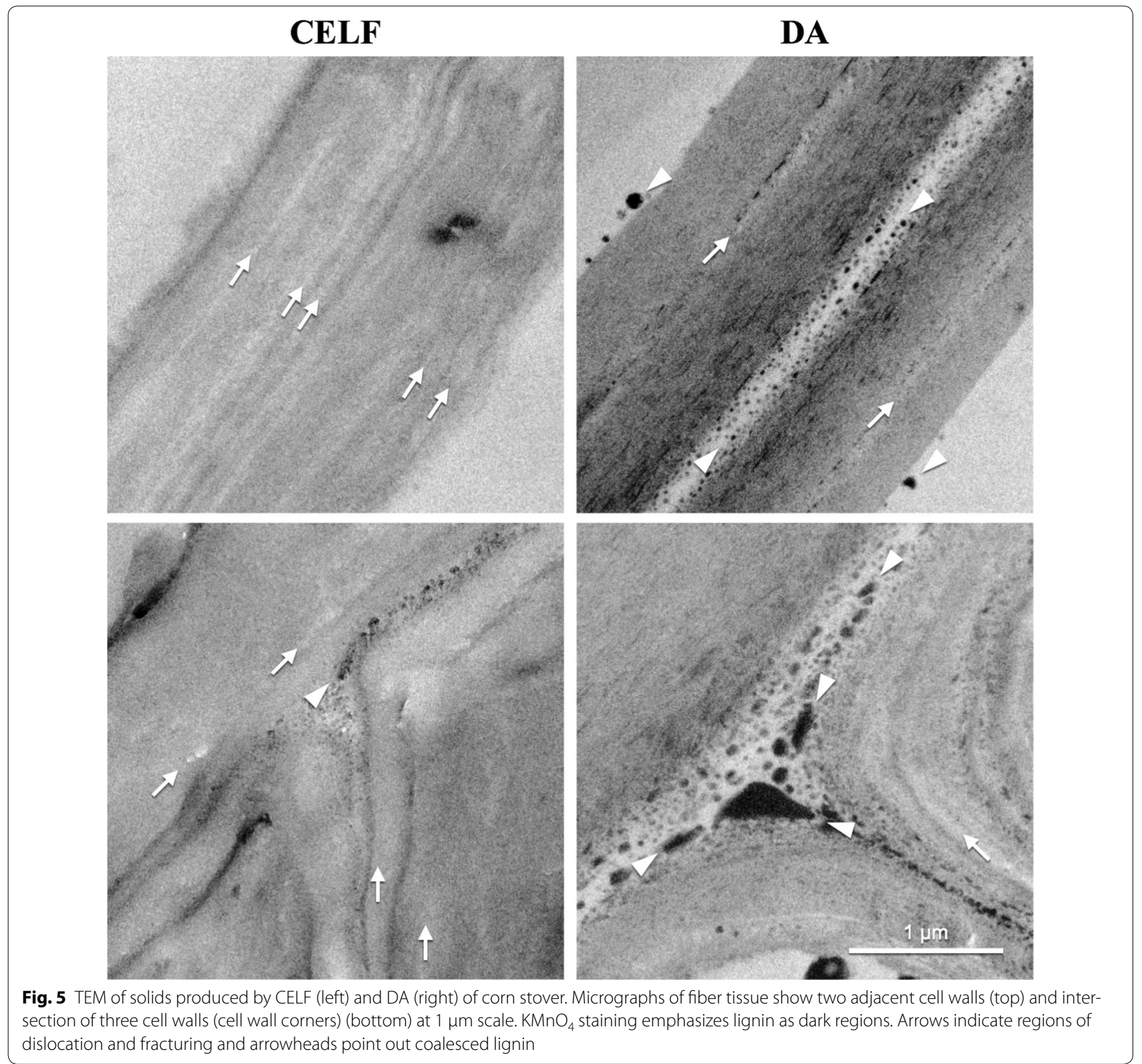

Table S2). Because FA is part of the lignin-carbohydrate complex (LCC) in herbaceous biomass, its removal could lead to LCC breakages that contribute to reduced recalcitrance [60]. In addition, comparison of 2D NMR spectra contours (Additional file 1: Figures S6 and S7) shows CELF removed more $p$ CA from corn stover and PB from Populus than DA. Preferable removal of lignin moieties by CELF provides new insight into key lignin components that may be responsible for efficient lignin release during biomass pretreatment. In turn, these interpretations are consistent with TEM results in Figs. 4 and 5 that show a cleaner surface in CELF-pretreated substrates due to enhanced lignin removal.

\section{Conclusions}

CELF proved more efficacious than DA for deconstructions of both corn stover and Populus in combination with fungal enzymes or $C$. thermocellum. However, the CELF-C. thermocellum tandem proved particularly effective in virtually eliminating differences in the native recalcitrances of corn stover and Populus with $C$. thermocellum almost completely deconstructing CELFpretreated solids at nearly identical enhanced rates. CELF-CBP also performed better than CELF followed by hydrolysis with reasonable loadings of fungal enzymes. Composition measurements and material balances, cellulase adsorption, and CSLM and TEM imaging revealed 


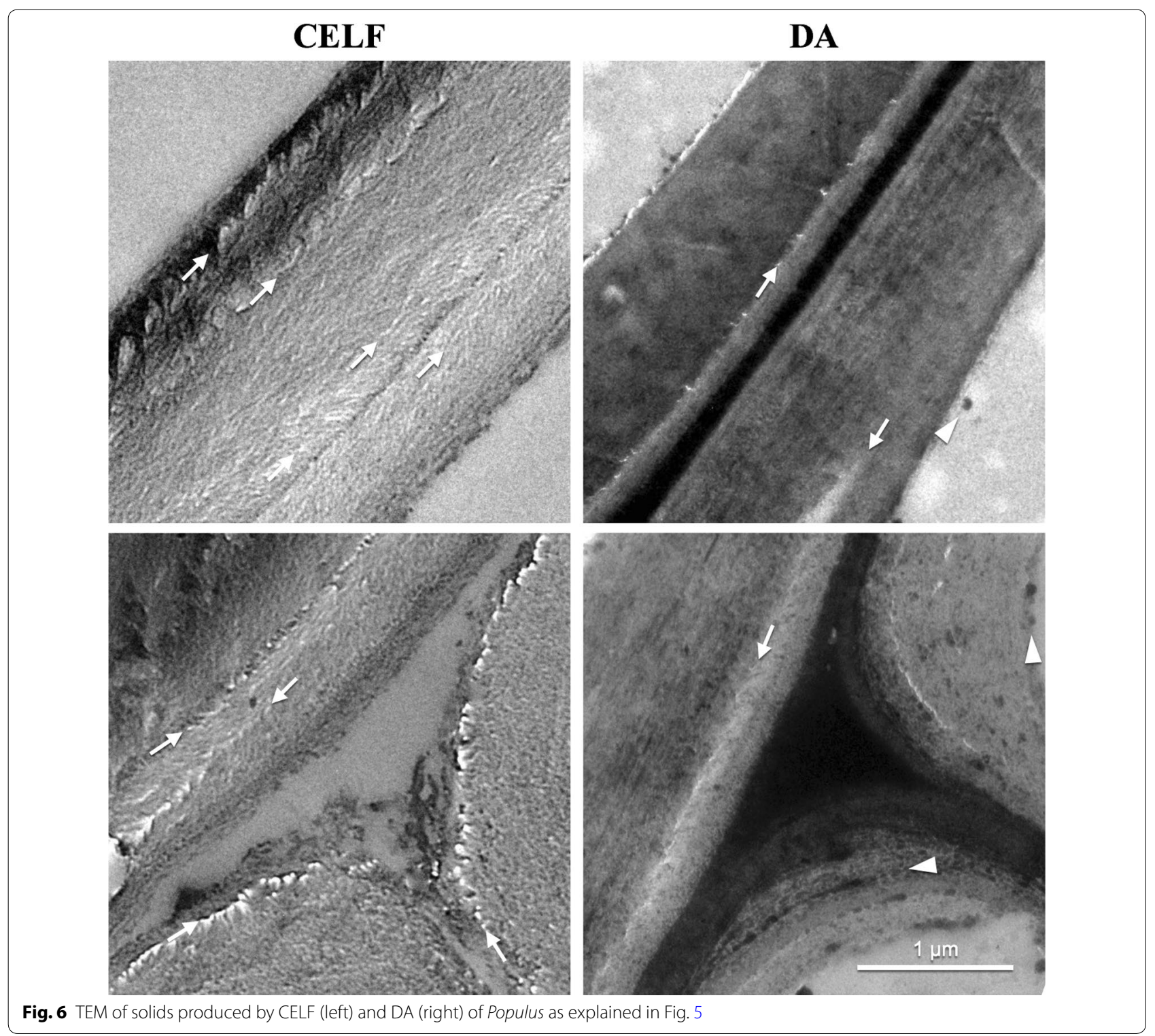

CELF pretreatment rendered corn stover more readily deconstructed by enzymes through high lignin removal, enhanced enzyme accessibility, increased fractures of cell walls, and cellular dislocation and cell wall delamination. In particular, solids produced by CELF pretreatment of corn stover and Populus adsorbed more cellulase, $\Gamma_{\max }$, than DA solids, despite reducing enzyme affinity, $K$. Interestingly, no clear trend was found between changes in lignin $S / G$ ratio and reduced recalcitrance in that CELF increased the $S / G$ ratio more than DA for corn stover but made a comparable change to DA of Populus. Overall, the possible correlation of enhanced deconstruction of CELF solids by fungal enzymes and, particularly C. thermocellum with lignin removal and alteration, points to these factors playing key roles in overcoming biomass recalcitrance as a barrier to low-cost biological conversion to sustainable fuels.

\section{Experimental}

\section{Materials and methods}

The BioEnergy Science Center (BESC) through the National Renewable Energy Laboratory (NREL, Golden, $\mathrm{CO}$ ) and Oak Ridge National Laboratory (ORNL, Oak Ridge, TN) provided corn stover, Zea mays, and chipped BESC standard Populus trichocarpa, respectively. The corn stover and BESC standard Populus, both with moisture contents below $10 \mathrm{w} / \mathrm{w} \%$, were knife milled (Thomas-Wiley Laboratory Mill, Model 4, Thomas 
Scientific, Swedesboro, NJ) through a $1 \mathrm{~mm}$ size screen to a particle size $<1 \mathrm{~mm}$. Material that passed through the screen was mixed, divided into 1 gallon bags, and stored at $-20{ }^{\circ} \mathrm{C}$. The small particle size was employed to be consistent with our previous work and avoid confusion by possible mass transfer artifacts due to intraparticle diffusion limitations. Microcrystalline cellulose powder, Avicel ${ }^{\circledR}$ PH-101 from Sigma-Aldrich (St. Louis, $\mathrm{MO}$ ), was stored at room temperature.

Corn stover and Populus were pretreated by dilute acid (DA) and Co-solvent Enhanced Lignocellulosic Fractionation (CELF). Figure 1 illustrates steps in this study, with pretreatment as Stage 1 and fungal enzymatic digestion or CBP fermentation as Stage 2. Pretreated solids were washed before biological digestion at low solids loadings to minimize end-product inhibition of enzymes. Raw and pretreated biomass solids composition, Stage 1 sugar balances, Stage 1 sugar recovery, and Stage 2 sugar release for fungal enzymes and $C$. thermocellum described in the Additional file 1 were used to determine sugar recovery for each feedstock, pretreatment, and biological catalyst combination. The sugar release for enzymatic hydrolysis refers to sugars recovered in the solution, as determined by direct measurement, while sugar release for CBP is the amount of sugars solubilized as determined by analysis of the carbohydrates in the residual solids.

Pretreatments were performed in a $1 \mathrm{~L}$ Hastelloy reactor (Parr Instrument Company, Moline, IL) equipped with a pressure gauge, thermocouple (Type K, Omega Engineering, Inc., Stamford, Connecticut), impeller, and electric motor [Pacific Scientific Automation Technology Group (Kollmorgen), Radford, VA]. The reactor was heated to temperature by lowering it into a fluidized sand bath (Model SBL-2D, Techne, Princeton, NJ) maintained at $350-375{ }^{\circ} \mathrm{C}$. The contents were mixed at $180 \mathrm{rpm}$. Reactor heat up time was that for the temperature to rise from ambient to within $2{ }^{\circ} \mathrm{C}$ of the target, the thermocouple accuracy limit. Temperature was controlled by raising and lowering the reactor at the surface of the sand bath. Reaction was stopped by transferring the reactor to a room temperature water bath with cool-down time being from target temperature to $80{ }^{\circ} \mathrm{C}$. The pretreated solids and liquor were separated by vacuum filtration, with liquor stored at $-20{ }^{\circ} \mathrm{C}$. Filtered solids were collected, weighed, and stored at $-20^{\circ} \mathrm{C}$ to prevent microbial degradation and compositional changes. Moisture content of solids was measured by oven drying.

Dilute sulfuric acid (DA), and co-solvent enhanced lignocellulosic fractionation (CELF) pretreatments were with $5-10 \mathrm{w} / \mathrm{w} \%$ solids loading for a $750-800 \mathrm{~g}$ total mass. For DA and CELF, untreated biomass was soaked in $0.5 \mathrm{w} / \mathrm{w} \%$ dilute sulfuric acid and a 50:50 (v:v) mixture of THF:dilute sulfuric acid $(0.5 \mathrm{w} / \mathrm{w} \%)$, respectively, for at least $4 \mathrm{~h}$ to allow catalyst penetration.

\section{Enzymatic hydrolysis}

Enzymatic hydrolysis followed the National Renewable Energy Laboratory (NREL, Golden, CO) procedure "Enzymatic Saccharification of Lignocellulosic Biomass" [61]. Loadings of fungal cellulase cocktail Accellerase ${ }^{\circledR}$ 1500 (DuPont Industrial Biosciences, Wilmington, DE; protein concentration $\sim 86 \mathrm{mg} / \mathrm{mL}$ ) were in $\mathrm{mg}$ protein $/ \mathrm{g}$ glucan in raw or pretreated biomass. Protein concentration was determined by a Pierce ${ }^{\mathrm{TM}}$ BCA protein assay kit (ThermoFisher Scientific, Pittsburgh, PA). As shown elsewhere, Accellerase ${ }^{\circledR} 1500$ contains some hemicellulases and auxiliary enzyme activities in addition to cellulase as a major component, $[62,63]$. Hydrolysis experiments were run in duplicate for up to 7 days in $125 \mathrm{~mL}$ flasks with a working volume of $50 \mathrm{~mL}$ at $50{ }^{\circ} \mathrm{C}$ and $150 \mathrm{rpm}$ in Multitron shakers (Model AJ125; Infors-HT, Laurel, $\mathrm{MD}, \mathrm{USA}$ ). $50 \mathrm{mM}$ sodium citrate buffer maintained $\mathrm{pH}$ at $5.0 \pm 0.1 .0 .2 \mathrm{~g} / \mathrm{L}$ sodium azide was added to prevent microbial growth. Enzyme blanks without substrate were incubated with samples to determine any sugar in the enzyme.

\section{Anaerobic digestion/consolidated bioprocessing} Clostridium thermocellum DSM 1313 was from Professor Lee R. Lynd, Dartmouth College (Hanover, NH). Seed inoculum was from a single batch of a mono-colony isolate of exponential phase $C$. thermocellum cultured in MTC medium [64] and Avicel ${ }^{\circledR} \mathrm{PH}-101$ at $60{ }^{\circ} \mathrm{C}$ and $180 \mathrm{rpm}$. Media chemicals were from Sigma-Aldrich (St. Louis, MO) or Fisher Scientific (Pittsburgh, PA). Seed inoculum was divided into $4 \mathrm{~mL}$ aliquots and stored at $-80{ }^{\circ} \mathrm{C}$. Freezer stocks were cultured on 5 g Avicel ${ }^{\circledR}$ $\mathrm{PH}-101$ glucan/L using MTC medium (less trace elements and yeast extract) for $2 \mathrm{v} / \mathrm{v} \%$ inoculum. $50 \mathrm{~mL}$ working volumes were loaded with $5 \mathrm{~g}$ glucan/L of pretreated biomass and transferred freezer stock cultures. Over a 4 year period, Avicel ${ }^{\circledR}$ controls were run at identical conditions to be sure the inoculum continued to reach $\sim 90 \%$ glucan release in $24 \mathrm{~h}$. Glucan release was calculated as glucan weight in solution after $24 \mathrm{~h}$ relative to the glucan weight loaded initially. To calculate solids dry weight after $24 \mathrm{~h}$, the entire fermentation contents were collected, washed (via vortexing as described later), and oven dried at $105{ }^{\circ} \mathrm{C}$ overnight. Details on yield and material balance calculations are presented in the Additional file 1 .

Cultures and media were in serum bottles plugged with butyl rubber stoppers (Chemglass Life Sciences, Vineland, NJ) and sealed by aluminum crimps. To make anaerobic, the headspace was flushed with nitrogen gas 
and then evacuated by a compressor (model ABF63 4B $7 R Q$, ATB, Vienna, Austria) for $45 \mathrm{~s}$. The flush/evacuation cycle was repeated 15 times. Biomass and substrates were autoclaved at $121{ }^{\circ} \mathrm{C}$ for $30 \mathrm{~min}$, and media autoclaved or filter sterilized $(0.22 \mu \mathrm{m}$ filter, Millipore, Billerica, MA) for heat sensitive compounds. Bottle fermentations were maintained at $\mathrm{pH} 7.0$ with MOPS buffer. All the anaerobic digestion experiments were run in duplicate, with mean values reported. Samples were at 12 or $24 \mathrm{~h}$ intervals for 7 days.

The entire reactor contents were centrifuged at $2800 \mathrm{rpm}$ to remove liquid for HPLC analysis, and residual solids were washed three times, each with $50 \mathrm{~mL}$ of DI water after vortexing solids and water between washings. Residual solids were dried and weighed to determine total mass loss followed by polysaccharide and lignin quantification.

\section{Structural sugars and lignin quantification}

Raw, pretreated, and post CBP solids were analyzed for structural sugars and lignin via NREL procedure "Determination of Structural Carbohydrates and Lignin in Biomass" [65]. Wheat straw (RM 8494) or Eastern Cottonwood (RM 8492) from the National Institute of Standards and Technology (Gaithersburg, MD) were also analyzed as standards. If $<300 \mathrm{mg}$ of solids remained after fermentation, the procedure was scaled down for the available sample weight.

Liquid samples from pretreatment, enzymatic hydrolysis, and fermentation were analyzed for soluble sugar monomers and oligomers by HPLC. To analyze monomers, $30 \mu \mathrm{L}$ of $10 \mathrm{w} / \mathrm{w} \%$ sulfuric acid was added to $1 \mathrm{~mL}$ enzymatic hydrolysis and fermentation samples to stop reactions, vortexed, and centrifuged to remove solids and cell debris prior to analysis. To quantify oligomers, liquid samples were post hydrolyzed per the NREL procedure "Determination of Structural Carbohydrates and Lignin in Biomass" [65].

A Waters HPLC separations module e2694 with refractive index detector 2414, (Milford, MA) and Aminex HPX-87H column (Bio-Rad, Hercules, CA) eluted with $50 \mathrm{mM}$ sulfuric acid separated cellobiose, glucose, xylose, arabinose, formate, lactate, acetate, levulinic acid, ethanol, 5-HMF, and furfural. Two to five replicates were run for each analysis.

\section{Cellulase adsorption}

Cellulase C2730 (T. reesei ATCC 26921, protein content $40 \mathrm{mg} / \mathrm{mL}$, Sigma-Aldrich) adsorption on $2 \%(\mathrm{w} / \mathrm{v})$-pretreated solids was at $4{ }^{\circ} \mathrm{C}$ in $50 \mathrm{mM}$ citrate buffer (pH 4.8) [66] over concentrations from 0.01 to $2.0 \mathrm{mg}$ protein $/ \mathrm{mL}$ (0.5-100 $\mathrm{mg}$ protein/g solids). The mixture was equilibrated at $4{ }^{\circ} \mathrm{C}$ for $2.5 \mathrm{~h}$ in 15 min shaking intervals. The supernatant cellulase protein content was determined by the Bradford assay using bovine serum albumin (BSA) as a standard [67]. Cellulase adsorption was calculated as the difference between initial cellulase added and cellulase left in supernatant. Cellulase adsorption on CELFand DA-pretreated biomass substrates was modeled by the classical Langmuir adsorption isotherm, with the adsorbed enzyme concentration $(I)$ calculated as:

$$
\Gamma=\frac{\Gamma_{\max } K C}{1+K C},
$$

where $\Gamma$ is bound enzyme ( $\mathrm{mg} / \mathrm{g}$ substrate), $\Gamma_{\max }$ the surface concentration of protein at full coverage $(\mathrm{mg} / \mathrm{g}$ substrate), $K$ the binding affinity constant $(\mathrm{mL} / \mathrm{mg})$, and $C$ the bulk solution protein concentration $(\mathrm{mg} / \mathrm{mL})$ [53].

\section{Imaging by stereoscopy, CSLM, and TEM}

Pretreated biomass and solid residues after $C$. thermocellum CBP were imaged by stereoscopy, CSLM, and TEM. For stereoscopy, a Nikon SMZ1500 stereomicroscope with a Nikon DS-Fi1 CCD camera operated by a Nikon Digital Sight system (Nikon Instruments, Melville, NY) examined biomass particles without further processing [68].

Prior to CSLM or TEM, biomass samples were fixed for $2 \times 6$ min (with variable power) in $2.5 \%$ gluteraldehyde buffered in $0.1 \mathrm{M}$ sodium cacodylate buffer (EMS, Hatfield, PA) under vacuum and dehydrated with increasing acetone concentrations $(15,30,60,90$, and $3 \times 100 \%$ acetone) for $1 \mathrm{~min}$ at each dilution. Samples were then infiltrated with LR White resin (EMS, Hatfield, PA) by incubating at room temperature (RT) for several hours to overnight in increasing concentrations of resin (30, $60,90,3 \times 100 \%$ resin, diluted in ethanol). Samples were transferred to capsules, and the resin was polymerized at $60{ }^{\circ} \mathrm{C}$ overnight. LR White embedded samples were sectioned to $\sim 60 \mathrm{~nm}$ with a Diatome diamond knife on a Leica EM UTC ultramicrotome (Leica, Wetzlar, Germany). Sections were collected on $0.5 \%$ Formvar coated slot grids (SPI Supplies, West Chester, PA).

For CSLM, $300 \mathrm{~nm}$ sectioned samples were positioned on glass microscope slides and stained with $0.1 \%$ acriflavine, a fluorochrome for lignin detection. Images were captured using a 40X 1.3NA Plan Fluor lens on a Nikon C1 Plus microscope (Nikon, Tokyo, Japan), equipped with a Nikon C1 confocal system operated via Nikon's EZ-C1 software and using $488 \mathrm{~nm}$ laser excitation. For TEM, $60 \mathrm{~nm}$ sections placed on grids were post-stained for $6 \mathrm{~min}$ with $2 \%$ aqueous uranyl acetate and $10 \mathrm{~min}$ with $1 \% \mathrm{KMnO} 4$ to selectively stain lignin. Images were captured by a 4-mega-pixel Gatan UltraScan 1000 camera (Gatan, Pleasanton, CA) on FEI Tecnai G2 20 Twin 200 kV LaB6 TEM (FEI, Hilsboro, OR). Additional details 
on preparation, microscopy execution, and image capture, curating, processing, and analysis for CSLM and TEM are described elsewhere [69].

\section{Heteronuclear single quantum coherence (HSQC) 2D-NMR of lignin relative monolignol subunit abundance determination}

Samples were freeze dried and extracted by ethanol:toluene $(1: 2, \mathrm{v} / \mathrm{v})$ via a Soxhlet apparatus before analysis. Lignin samples were isolated by dioxane:water (96:4, v/v) extraction after ball-milling by a Retsch PM 100 planetary mill and treatment with mixed cellulolytic enzymes (Cellic ${ }^{\circledR} \mathrm{CTec} 2$ and HTec2, gifts from Novozyme). Lignin samples obtained were dissolved in $\mathrm{DMSO}_{-\mathrm{d} 6}$ using a Shigemi micro-tube, and lignin spectra were acquired with a $400-\mathrm{MHz}$ Bruker Avance-III spectrometer. HSQC experiments applied a 10-ppm spectra width in $\mathrm{F} 2\left({ }^{1} \mathrm{H}\right)$ dimension with 2048 data points, 210ppm spectra width in $\mathrm{F} 1\left({ }^{13} \mathrm{C}\right)$ dimension with 256 data points, 1.5-s pulse delay, and a ${ }^{1} J_{\mathrm{C}-\mathrm{H}}$ coupling constant of $145 \mathrm{~Hz} .128$ or 320 scans were employed depending on sample concentration. The central DMSO solvent peak $\left(\delta_{\mathrm{C}} 39.5 \mathrm{ppm} ; \delta_{\mathrm{H}} 2.49 \mathrm{ppm}\right)$ was used for chemical shift calibration. NMR data were processed using TopSpin 2.1 (Bruker BioSpin) software packages [70].

\section{Additional file}

Additional file 1. Additional information.

\begin{abstract}
Abbreviations
CBP: consolidated bioprocessing by a single organism, in this case, Clostridium thermocellum that produces cellulolytic enzymes and ferments the sugars released in a single vessel; CELF: pretreatment with a miscible mixture of tetrahydrofuran (THF) and an equal volume of $0.5 \%$ sulfuric acid in water; CELF-CS: solids produced by CELF pretreatment of corn stover; CELF-POP: solids produced by CELF pretreatment of Populus; CSLM: confocal scanning light microscopy; DA: pretreatment with dilute sulfuric acid, in this case, $0.5 \%$ sulfuric acid at $160^{\circ} \mathrm{C}$; DA-CS: solids produced by DA pretreatment of corn stover; DA-POP: solids produced by DA pretreatment of Populus; HSQC: heteronuclear single quantum coherence 2D-NMR; NMR: nuclear magnetic resonance; TEM: transmission electron microscopy.
\end{abstract}

\section{Authors' contributions}

$V T$ performed the CELF pretreatments and CBP fermentations, performed composition and mass measurements for these systems, calculated yields, and wrote the initial draft of the results. BSD performed all imaging experiments, provided the images in the manuscript, and wrote and edited relevant portions of the paper. ML, YP, and AJR developed enzyme adsorption and HSQC NMR data and wrote sections relevant to both. RK helped direct the research, analyze data, and write the paper. TYN performed CELF pretreatments and enzymatic hydrolysis studies on corn stover. CMC provided direction for CELF pretreatments, calculations, and helped write the paper. CEW led the team in designing and guiding this research, pulling together written material from the various experiments, and writing and submitting the final paper. All authors read and approved the final manuscript.

\begin{abstract}
Author details
${ }^{1}$ Department of Chemical and Environmental Engineering, Bourns College of Engineering, University of California Riverside, Riverside, CA, USA. ${ }^{2}$ Center for Environmental Research and Technology (CE-CERT), Bourns College of Engineering, University of California Riverside, Riverside, CA, USA. ${ }^{3}$ National Renewable Energy Laboratory, Golden, CO, USA. ${ }^{4}$ Joint Institute of Biological Science, Biosciences Division, Oak Ridge National Laboratory (ORNL), Oak Ridge, TN, USA. ${ }^{5}$ Department of Chemical \& Bimolecular Engineering, Center for Renewable Carbon and Department of Forestry, Wild life, and Fisheries, University of Tennessee Knoxville, Knoxville, TN, USA. ${ }^{6}$ Department of Bioengineering, Bourns College of Engineering, University of California Riverside, Riverside, CA, USA. ${ }^{7}$ BioEnergy Science Center (BESC), Oak Ridge National Laboratory, Oak Ridge, TN, USA.
\end{abstract}

\section{Acknowledgements}

We gratefully acknowledge funding by the Office of Biological and Environmental Research in the DOE Office of Science through the BioEnergy Science Center (BESC), a DOE Bioenergy Research Center and support of a member of our team by a National Science Foundation grant (\#2013142496). We also recognize the Ford Motor Company Chair in Environmental Engineering at the University of California Riverside (UCR). NREL is a national laboratory of the US Department of Energy Office of Energy Efficiency and Renewable Energy operated by the Alliance for Sustainable Energy, LLC. This manuscript has been co-authored by UT-Battelle, LLC under contract DE-AC05-00OR22725 with the US Department of Energy. The publisher, by accepting the article for publication, acknowledges that the United States Government retains a non-exclusive, paid-up, irrevocable, worldwide license to publish or reproduce the published form of this manuscript, or allow others to do so, for the United States Government purposes. The Department of Energy will provide public access to these results of federally sponsored research in accordance with the DOE Public Access Plan (http://energy.gov/downloads/doe-public-accessplan). The valuable assistance of the team of Professor Lynd at the Dartmouth College in providing the $C$. thermocellum strain and training in its use is highly appreciated.

\section{Competing interests}

Funding for this research was provided by the Office of Biological and Environmental Research in the DOE Office of Science through the BioEnergy Science Center (BESC), a DOE Bioenergy Research Center. In addition, one author was supported by a National Science Foundation grant (\#2013142496). We also recognize the Ford Motor Company Chair in Environmental Engineering at the University of California Riverside (UCR). None of these funding bodies designed the study, collected, analyzed, or interpreted data, or contributed to writing the manuscript.

\section{Availability of data and materials}

The datasets used and/or analyzed during the current study are available from the corresponding author on reasonable request.

\section{Consent for publication}

Not applicable.

Ethics approval and consent to participate Not applicable.

\section{Publisher's Note}

Springer Nature remains neutral with regard to jurisdictional claims in published maps and institutional affiliations.

Received: 14 July 2017 Accepted: 19 October 2017

Published online: 30 November 2017

\section{References}

1. Dale BE, Anderson JE, Brown RC, Csonka S, Dale VH, Herwick G, Jackson RD, Jordan N, Kaffka S, Kline KL, et al. Take a closer look: biofuels can support environmental, economic and social goals. Environ Sci Technol. 2014;48(13):7200-3. 
2. Fulton LM, Lynd LR, Körner A, Greene N, Tonachel LR. The need for biofuels as part of a low carbon energy future. Biofuels Bioprod Biorefin. 2015;9(5):476-83.

3. Hill J, Polasky S, Nelson E, Tilman D, Huo H, Ludwig L, Neumann J, Zheng $\mathrm{H}$, Bonta D. Climate change and health costs of air emissions from biofuels and gasoline. Proc Natl Acad Sci. 2009;106(6):2077-82.

4. Lal R. Carbon sequestration. Philos Trans R Soc B. 2008;363(1492):815.

5. Himmel ME, Ding SY, Johnson DK, Adney WS, Nimlos MR, Brady JW, Foust TD. Biomass recalcitrance: engineering plants and enzymes for biofuels production. Science. 2007;315(5813):804-7.

6. Ding S-Y, Liu Y-S, Zeng Y, Himmel ME, Baker JO, Bayer EA. How does plant cell wall nanoscale architecture correlate with enzymatic digestibility? Science. 2012;338(6110):1055-60.

7. Ragauskas AJ, Beckham GT, Biddy MJ, Chandra R, Chen F, Davis MF, Davison BH, Dixon RA, Gilna P, Keller M, et al. Lignin valorization: improving lignin processing in the biorefinery. Science. 2014;344(6185):709.

8. Ragauskas AJ, Williams CK, Davison BH, Britovsek G, Cairney J, Eckert CA, Frederick WJ Jr, Hallett JP, Leak DJ, Liotta CL, et al. The path forward for biofuels and biomaterials. Science. 2006;311(5760):484-9.

9. Zhu H, Luo W, Ciesielski PN, Fang Z, Zhu JY, Henriksson G, Himmel ME, Hu L. Wood-derived materials for green electronics, biological devices, and energy applications. Chem Rev. 2016;116(16):9305-74.

10. Langholtz MH, Stokes BJ, Eaton LM. 2016 Billion-ton report: advancing domestic resources for a thriving bioeconomy, vol 1. In: Economic availability of feedstocks; 2016. p. 448.

11. Perlack RD, Stokes BJ: U.S. Billion-Ton Update. Biomass supply for a bioenergy and bioproducts industry. In.: US Department of Energy, Oak Ridge: Oak Ridge National Laboratory; 2011: p. 227.

12. Gnansounou E, Dauriat A. Techno-economic analysis of lignocellulosic ethanol: a review. Bioresour Technol. 2010;101(13):4980-91.

13. Wyman CE. Ethanol from lignocellulosic biomass - technology, economics, and opportunities. Bioresour Technol. 1994;50(1):3-16.

14. Wyman CE. What is (and is not) vital to advancing cellulosic ethanol. Trends Biotechnol. 2007;25(4):153-7.

15. Lynd LR, Wyman CE, Gerngross TU. Biocommodity engineering. Biotechnol Progr. 1999;15(5):777-93.

16. Percival Z Y-H. What is vital (and not vital) to advance economically-competitive biofuels production. Process Biochem. 2011;46(11):2091-110.

17. Lynd LR, Cushman JH, Nichols RJ, Wyman CE. Fuel ethanol from cellulosic biomass. Science. 1991;251(4999):1318-23.

18. Horn S, Vaaje-Kolstad G, Westereng B, Eijsink V. Novel enzymes for the degradation of cellulose. Biotechnol Biofuels. 2012;5(1):45.

19. Reese ET. Enzymatic hydrolysis of cellulose. Appl Microbiol. 1956:4(1):39-45.

20. Klein-Marcuschamer D, Oleskowicz-Popiel P, Simmons BA, Blanch HW. The challenge of enzyme cost in the production of lignocellulosic biofuels. Biotechnol Bioeng. 2012;109(4):1083-7.

21. Merino Sandra T, Cherry J. Progress and challenges in enzyme development for biomass utilization. Adv Biochem Eng Biotechnol. 2007; 108:95-120.

22. Mosier N, Wyman C, Dale B, Elander R, Lee YY, Holtzapple M, Ladisch M. Features of promising technologies for pretreatment of lignocellulosic biomass. Bioresour Technol. 2005;96(6):673-86.

23. Falls M, Shi J, Ebrik MA, Redmond T, Yang B, Wyman CE, Garlock R, Balan V, Dale BE, Pallapolu VR, et al. Investigation of enzyme formulation on pretreated switchgrass. Bioresour Technol. 2011;102(24):11072-9.

24. Kumar R, Wyman CE. Effect of enzyme supplementation at moderate cellulase loadings on initial glucose and xylose release from corn stover solids pretreated by leading technologies. Biotechnol Bioeng. 2009;102(2):457-67.

25. Uppugundla N, da Costa Sousa L, Chundawat S, Yu X, Simmons B, Singh S, Gao X, Kumar R, Wyman C, Dale B, et al. A comparative study of ethanol production using dilute acid, ionic liquid and AFEXTM pretreated corn stover. Biotechnol Biofuels. 2014;7(1):72

26. Wyman CE, Dale BE, Balan V, Elander RT, Holtzapple MT, Ramirez RS, Ladisch MR, Mosier NS, Lee YY, Gupta R et al. Comparative performance of leading pretreatment technologies for biological conversion of corn stover, poplar wood, and switchgrass to sugars. In: Aqueous pretreatment of plant biomass for biological and chemical conversion to fuels and chemicals. New Jersey: Wiley; 2013. 239-259.
27. Lloyd TA, Wyman CE. Combined sugar yields for dilute sulfuric acid pretreatment of corn stover followed by enzymatic hydrolysis of the remaining solids. Bioresour Technol. 2005;96(18):1967-77.

28. Rasmussen H, Sørensen HR, Meyer AS. Formation of degradation compounds from lignocellulosic biomass in the biorefinery: sugar reaction mechanisms. Carbohydr Res. 2014;385:45-57.

29. Veldhuis MK, Christensen LM, Fulmer El. Production of ethanol: by thermophilic fermentation of cellulose. Ind Eng Chem. 1936;28(4):430-3.

30. Olson DG, McBride JE, Joe Shaw A, Lynd LR. Recent progress in consolidated bioprocessing. Curr Opin Biotechnol. 2012;23(3):396-405.

31. Kataeva I, Foston MB, Yang S-J, Pattathil S, Biswal AK, Poole FL, Basen M, Rhaesa AM, Thomas TP, Azadi P, et al. Carbohydrate and lignin are simultaneously solubilized from unpretreated switchgrass by microbial action at high temperature. Energy Environ Sci. 2013;6(7):2186-95.

32. Xu Q, Resch MG, Podkaminer K, Yang S, Baker JO, Donohoe BS, Wilson C, Klingeman DM, Olson DG, Decker SR, et al. Dramatic performance of Clostridium thermocellum explained by its wide range of cellulase modalities. Sci Adv. 2016;2(2):e1501254.

33. Bayer EA, Lamed R, Himmel ME. The potential of cellulases and cellulosomes for cellulosic waste management. Curr Opin Biotechnol. 2007;18(3):237-45.

34. Moraïs S, Morag E, Barak Y, Goldman D, Hadar Y, Lamed R, Shoham Y, Wilson DB, Bayer EA. Deconstruction of lignocellulose into soluble sugars by native and designer cellulosomes. MBio 2012; 3(6), e00508-12.

35. Tian L, Papanek B, Olson DG, Rydzak T, Holwerda EK, Zheng T, Zhou J, Maloney M, Jiang N, Giannone RJ, et al. Simultaneous achievement of high ethanol yield and titer in Clostridium thermocellum. Biotechnol Biofuels. 2016;9(1):116.

36. Lynd LR, Grethlein HE. Hydrolysis of dilute acid pretreated mixed hardwood and purified microcrystalline cellulose by cell-free broth from Clostridium thermocellum. Biotechnol Bioeng. 1987;29(1):92-100.

37. Shao X, Jin M, Guseva A, Liu C, Balan V, Hogsett D, Dale BE, Lynd L. Conversion for Avicel and AFEX pretreated corn stover by Clostridium thermocellum and simultaneous saccharification and fermentation: insights into microbial conversion of pretreated cellulosic biomass. Bioresour Technol. 2011;102(17):8040-5.

38. Wyman CE, Balan V, Dale BE, Elander RT, Falls M, Hames B, Holtzapple MT, Ladisch MR, Lee YY, Mosier N, et al. Comparative data on effects of leading pretreatments and enzyme loadings and formulations on sugar yields from different switchgrass sources. Bioresour Technol. 2011;102(24):11052-62.

39. Wyman CE, Dale BE, Elander RT, Holtzapple M, Ladisch MR, Lee YY, Mitchinson C, Saddler JN. Comparative sugar recovery and fermentation data following pretreatment of poplar wood by leading technologies. Biotechnol Prog. 2009;25(2):333-9.

40. Humbird D, Davis R, Tao L, Kinchin C, Hsu D, Aden A, Schoen P, Lukas J, Olthof B, Worley M, et al. Process design and economics for biochemical conversion of lignocellulosic biomass to ethanol: NREL/TP-5100-47764. In: National Renewable Energy Laboratory; 2011.

41. Tao L, Schell D, Davis R, Tan E, Elander R, Bratis A. NREL 2012 achievement of ethanol cost targets: Biochemical ethanol fermentation via diluteacid pretreatment and enzymatic hydrolysis of corn stover. In.: Golden: National Renewable Energy Laboratory (NREL); 2014.

42. Nguyen TY, Cai CM, Kumar R, Wyman CE. Co-solvent pretreatment reduces costly enzyme requirements for high sugar and ethanol yields from lignocellulosic biomass. Chemsuschem. 2015;8(10):1716-25.

43. Mostofian B, Cai CM, Smith MD, Petridis L, Cheng X, Wyman CE, Smith JC. Local phase separation of co-solvents enhances pretreatment of biomass for bioenergy applications. J Am Chem Soc. 2016;138(34):10869-78.

44. Mellmer MA, Martin Alonso D, Luterbacher JS, Gallo JMR, Dumesic JA. Effects of [gamma]-valerolactone in hydrolysis of lignocellulosic biomass to monosaccharides. Green Chem. 2014;16(11):4659-62.

45. https://terathane.invista.com/en/knowledge-center: https://terathane. invista.com/en/knowledge-center. Accessed Mar 2015

46. Cai CM, Zhang T, Kumar R, Wyman CE. THF co-solvent enhances hydrocarbon fuel precursor yields from lignocellulosic biomass. Green Chem. 2013;15(11):3140-5.

47. Grethlein HE, Converse AO. Common aspects of acid prehydrolysis and steam explosion for pretreating wood. Bioresour Technol. 1991:36(1):77-82. 
48. Tao L, Tan ECD, McCormick R, Zhang M, Aden A, He X, Zigler BT. Technoeconomic analysis and life cycle assessment of cellulosic isobutanol and comparison with cellulosic ethanol and $n$-butanol. Biofuels Bioprod Biorefin. 2014;8(1):30-48.

49. Knappert D, Grethlein H, Converse A. Partial acid hydrolysis of cellulosic materials as a pretreatment for enzymatic hydrolysis. Biotechnol Bioeng 1980;22(7):1449-63.

50. Stephen JD, Mabee WE, Saddler JN. Will second-generation ethanol be able to compete with first-generation ethanol? Opportunities for cost reduction. Biofuels Bioprod Biorefin. 2012;6(2):159-76.

51. Kumar R, Wyman CE. Strong cellulase inhibition by Mannan polysaccharides in cellulose conversion to sugars. Biotechnol Bioeng. 2014;111(7):1341-53.

52. Qing Q, Yang B, Wyman CE. Xylooligomers are strong inhibitors of cellulose hydrolysis by enzymes. Bioresour Technol. 2010;101(24):9624-30.

53. Lynd LR, Weimer PJ, van ZyI WH, Pretorius IS. Microbial cellulose utilization: fundamentals and biotechnology. Microbiol Mol Biol Rev. 2002;66(3):506-77.

54. Baig K, Turcotte G, Doan H. Adsorption of cellulose enzymes on lignocellulosic materials and influencing factors: a review. Int J Water Res D 2016; 6(3).

55. Kumar R, Wyman CE. Physical and chemical features of pretreated biomass that influence macro-/micro-accessibility and biological processing. In: Aqueous pretreatment of plant biomass for biological and chemical conversion to fuels and chemicals. New Jersey: Wiley; 2013. 281-310.

56. Yarbrough JM, Mittal A, Mansfield E, Taylor LE, Hobdey SE, Sammond DW, Bomble YJ, Crowley MF, Decker SR, Himmel ME, et al. New perspective on glycoside hydrolase binding to lignin from pretreated corn stover. Biotechnol Biofuels. 2015:8(1):214

57. Donohoe BS, Decker SR, Tucker MP, Himmel ME, Vinzant TB. Visualizing lignin coalescence and migration through maize cell walls following thermochemical pretreatment. Biotechnol Bioeng. 2008;101(5):913-25.

58. Yang B, Wyman CE. BSA treatment to enhance enzymatic hydrolysis of cellulose in lignin containing substrates. Biotechnol Bioeng. 2006;94(4):611-7.

59. Studer MH, DeMartini JD, Davis MF, Sykes RW, Davison B, Keller M, Tuskan GA, Wyman CE. Lignin content in natural Populus variants affects sugar release. Proc Natl Acad Sci. 2011;108(15):6300-5.

60. Chundawat SPS, Beckham GT, Himmel ME, Dale BE. Deconstruction of lignocellulosic biomass to fuels and chemicals. Annu Rev Chem Biomol Eng. 2010;2(6):1-25.
61. Selig M, Weiss N, Ji Y. Enzymatic saccharification of lignocellulosic biomass. In. Golden, CO: laboratory analytical procedures (LAPS), National Renewable Energy Laboratory; 2008

62. Maitan-Alfenas GP, Oliveira MB, Nagem RAP, de Vries RP, Guimarães VM. Characterization and biotechnological application of recombinant xylanases from Aspergillus nidulans. Int J Biol Macromol. 2016;91:60-7.

63. Chundawat SPS, Lipton MS, Purvine SO, Uppugundla N, Gao D, Balan V, Dale BE. Proteomics-based Compositional analysis of complex cellulasehemicellulase mixtures. J Proteome Res. 2011;10(10):4365-72.

64. Hogsett D. Cellulose hydrolysis and fermentation by Clostridium thermocellum. Dartmouth College; 1995.

65. Sluiter A, Hames B, Ruiz R, Scarlata C, Sluiter J, Templeton D, Crocker D. Determination of structural carbohydrates and lignin in biomass. In: Laboratory Analytical Procedures (LAPs). Golden: National Renewable Energy Laboratory; 2008.

66. Li M, Tu M, Cao D, Bass P, Adhikari S. Distinct roles of residual xylan and lignin in limiting enzymatic hydrolysis of organosolv pretreated loblolly pine and sweetgum. J Agric Food Chem. 2013;61(3):646-54.

67. Bradford MM: A rapid and sensitive method for the quantitation of microgram quantities of protein utilizing the principle of protein-dye binding. Anal Biochem 1976;72(1-2):248-254

68. Wang W, Chen X, Donohoe B, Ciesielski P, Katahira R, Kuhn E, Kafle K, Lee C, Park S, Kim S, et al. Effect of mechanical disruption on the effectiveness of three reactors used for dilute acid pretreatment of corn stover part 1: chemical and physical substrate analysis. Biotechnol Biofuels. 2014;7(1):57.

69. Donohoe BS, Ciesielski PN, Vinzant TB. Preservation and preparation of lignocellulosic biomass samples for multi-scale microscopy analysis. Biomass Convers. 2012:908:31-47.

70. Yoo CG, Pu Y, Li M, Ragauskas AJ. Elucidating Structural Characteristics of Biomass using Solution-State 2 D NMR with a Mixture of Deuterated Dimethylsulfoxide and Hexamethylphosphoramide. Chemsuschem. 2016:9(10):1090-5.

\section{Submit your next manuscript to BioMed Central and we will help you at every step:}

- We accept pre-submission inquiries

- Our selector tool helps you to find the most relevant journal

- We provide round the clock customer support

- Convenient online submission

- Thorough peer review

- Inclusion in PubMed and all major indexing services

- Maximum visibility for your research

Submit your manuscript at www.biomedcentral com/submit 